\title{
Historical Approaches to Leaving Religion
}

\author{
Ryan Szpiech
}

\section{1 \\ Introducing Historical Approaches to Leaving Religion}

In the early fourteenth century, the Castilian Jew Abner of Burgos (d. ca. 1347) embraced the Christian religion and began to call himself Alfonso of Valladolid after changing his city of residence. He passed the remaining three decades of his life writing extensive polemics against Judaism, not in Latin, but in Hebrew, some of which he and possibly others translated into Castilian. Although there is no evidence that the sincerity of his conversion was ever in question among his Christian brethren, Abner/Alfonso - he is known by both names, depending on the sources - became one of the Christian anti-Jewish polemical writers who was most often cited by Jews, a majority of whom roundly condemn him as a liar, traitor, and apostate (Szpiech 2013: 144-150).

Abner/Alfonso's reputation among Jews as a notorious apostate has persisted to the twentieth century. Historian Yitzhaq Baer, states, "Abner did not belong in the fold of orthodox Catholicism; he was a typical mumar, a heretic within the Jewish camp" (Baer 1961: 1:334). Yet even though his "heresy" was commonplace, his reputation was not, for as word of his actions spread, he became no less than "the best known apostate ever to arise in medieval Jewry" (328). For Baer, Abner/Alfonso's identity as an apostate relies on the lingering persistence of his Jewish identity, his remaining within the Jewish fold rather than leaving it. For Baer, Abner/Alfonso "remained a Jew at heart." (334). Yet not all historians agree, and some see him as a traitor who left Judaism (for example, Shamir 1975: 53, who deems him a "true convert"). Raphale Jospe sums up the problem, posing the question, "Do we treat such thinkers and their works as Jewish, as Jewish until the time of their apostasy, or as non-Jewish and having no place in the context of Jewish philosophy?" (Jospe 1988: 9, my translation). If Abner/Alfonso was a "Jew at heart" who remained "within the Jewish camp," was his departure from Judaism insincere and incomplete? Must he be deemed a "true convert" (and so also a "true apostate") in order to "leave" one religion for another?

Abner/Alfonso's life and works present historians with a vexing question about scholarly methodology: how can one approach without bias the subject of leaving religion in historical sources? The question springs from a broader 
methodological challenge that confronts all historical study of religious identity: how can the differences between beliefs and practices, whether on an individual or collective level, be historicised in objective, or at least neutral, terms? The goal of this chapter is to introduce basic historical approaches to the subject of leaving religion and to point out the challenges that such approaches face. The discussion that follows will first provide a brief overview of past and contemporary approaches to the historical study of leaving religion. It will then provide a brief critical evaluation of such methodologies, offering a few recommendations for future methodological avenues.

\section{Theoretical Perspectives and Turning Points}

As in modern religious studies, leaving religion in a historical context has not been studied as a topic on its own until very recently. Generally speaking, it has been approached as a subtopic of conversion studies, and this conflation has brought with it a number of theoretical problems and challenges. Most problematic is the imposition, often unintentional, of a hierarchy of values in which faith and piety are implicitly held to be positive and normal while loss of faith and departure from religious belief or practice are characterised as negative and deviant. Such a hierarchy is certainly evident in the earliest scholarly literature on conversion. For example, William James, in his foundational 1902 study of religious experience, negatively casts leaving religion as "backsliding" and conversion as positive, a "high-water mark of [man's] spiritual capacity" (James 1987: 237). Such a view casts unfavourable judgment on leaving faith and regards it as a purely negative force that "diminishes" the individual's spiritual capacity. Later studies based on his model have inadvertently perpetuated a similarly hierarchical structure by accepting pre- or early modern paradigms of faith as natural and given rather than as culturally and historically determined. Overcoming the persistence of such assumptions is an important challenge for contemporary studies of entering or leaving religion.

Arthur Nock's 1933 study, Conversion, the first truly scholarly treatment of the subject in a historical context, constitutes the first serious effort to move away from such an implicit hierarchy. In contradistinction to conversion as an inner act of faith, he introduces what he calls "adhesion" to a religious tradition both from within and outside of the believer's faith community. He even goes so far as to present conversion to Christianity from the perspective of an ancient pagan like Celsus (second century) for whom "Christianity is primarily a mass movement of falling away from tradition” (Nock 1933: 207). Because he considers religious change not only in terms of entering religion or acquiring faith but also in terms of conversion as a falling away from tradition, he might 
be taken as a distant founding figure in the modern study of leaving religion and deconversion.

Despite the possibilities opened up by Nock's intervention (many of which Nock himself did not explore), much historical literature from the middle of the twentieth century continued to treat leaving religion as a sub-topic of the study of conversion. Historians of the medieval world have tended to approach it only through related categories such as heresy, apostasy, unorthodoxy (Grundmann 1953; Russell 1965; Leff 1967; Moore 1975; Kanarfogel 2012) while historians of the later medieval and early modern period represent dissent from tradition in terms of doubt, scepticism, or secularisation (Febvre 1937; Popkin 1979; Tuck 1988; Edwards 1988; Cohen 1999). While the former group sometimes treats deviation from or abandonment of normative belief according to medieval categories of faith and heresy, the latter tend to suffer from an implicit teleology that champions the story of scepticism as the story of modern secularism and Enlightenment reason.

An important theoretical shift in the scholarly literature of religious experience has accompanied the so-called linguistic turn in historiography over the last half-century, when intellectual and religious historiography has begun to engage more directly with questions of language as a mediator and determining factor not only of religious meaning and experience (Proudfoot 1985) but also of historical meaning (Skinner 1969; Jay 1982; Toews 1987; Spiegel 1990). This turn in historiography follows the lead of Michel Foucault, for whom "discourse is not the majestically unfolding manifestation of a thinking, knowing, speaking subject" (1972: 54). Because historical evidence always exists as a "discursive formation" that makes sense only in a particular context, historians must take care to "disconnect the unquestioned continuities by which we organise, in advance, the discourses that we are to analyse" (25). The approach to historical sources as forms of discourse in need of decoding and interpretation rather than as transparent stores of "data" about social and economic historical facts, has provoked a sense of crisis in the discipline, especially many parts of Europe, where social historiography still remains committed to traditional methodologies (Vásquez García 2004). As Nicola Clark explains, the resistance to the influence of cultural and literary studies points to the deep and "unsettling" shift that it has implied for accepted historiographical methodologies.

If the "real" is known only in and through its discursive construction (...) how could historians assume (as they customarily had) the adequacy of words to refer to things? (...) If language does not refer in a one-to-one fashion to things in the "real world," how could historians argue that their language about the past corresponded to "what had actually happened?"

CLARK 2004: 6 
Facing the question imposed by discourse has involved two important shifts in religious studies: the awareness of religious change (entering or leaving religion) defined not as a historical event but as a lived experience always mediated by symbols; and the awareness that the representation of that experience, in language or other symbolic structures, is not simply reflective but is actually constitutive of the experience itself. As Proudfoot explains, "the labels a person adopts in order to understand what is happening to him determine what he experiences" (1985: 229).

Some scholars in the social sciences have adopted an approach to their sources based on discourse analysis. Stromberg, for example, has based his anthropological study of conversion narratives on the premise that "the event is a symbolic construction" (Stromberg 1993: 15, 133 n. 10) and Leone has adopted a "semiotic" approach (2004). Nevertheless, the linguistic turn has also led to the characterisation of conversion and apostasy as a "historiographical problem" (Szpiech 2017) in which "a great divide opens between eleventh- and twelfthcentury ideas about conversion and modern studies in sociology, anthropology, and history" (Morrison 1992: xv).

Yet the effect of this shift need not only be received as negative. Rather than seeing all examples of leaving religion as a "falling away" from tradition or loss of faith, the linguistic turn has provoked a heightened attention to the role of individual testimony in characterising movements of faith, whether towards or away from participation, orthodoxy, or belief. This historiographical relativism resulting from the "linguistic turn" constitutes one of the most important turning points in the study of conversion and leaving religion over the last century and has led to the generalised view that any conversion can also be seen as an apostasy from another, contrary faith and, vice versa, that all leaving religion can be potentially understood in positive terms as the discovery of a new understanding and worldview. As Lewis Rambo explains, "Some forms of conversion also require an apostasy. Some conversions require explicit and enacted rejection of past affiliations, but all conversions implicitly require a leaving-behind or a reinterpretation of some past way of life and set of beliefs" (Rambo 1993: 53). A good example of this two-sided treatment in a historical context is Segal (1992), which presents the "conversion" of Paul as both a finding of new faith and an "apostasy" and departure from Judaism. Similarly, Malkiel (2007:6) considers the image of Jewish apostates in medieval Ashkenaz who "hurdled the Jewish-Christian divide with ease, as if they did not consider it terribly significant." Such approaches that are cognizant of the two-sided nature of religious change, whether movement between religions or departure from religion altogether, have more successfully avoided the distortions that 
caricature religious change only in negative terms as loss and apostasy or in positive terms as triumph and enlightenment.

\section{$3 \quad$ Methodological Perspectives and Turning Points}

Most studies that mention apostasy include it in studies of conversion, considered both in broad, social terms (such as the "Christianization" of Europe or the "Islamization" of the Levant, for example Jones 1962; Aubin 1963; Bulliet 1979; Fletcher 1997) and in narrow individual ones (such as the stories of individual apostates). Both of these approaches developed under the influence of French historiographical trends associated with the Annales school, which reformed positivist historiographical trends of the late nineteenth and early twentieth century by taking a more critical approach informed by the growth of other social sciences such as sociology and anthropology. One of the most influential methodologies in European history in the middle decades of the twentieth century was the history of "mentalities" that grew from the Annales school in France. Annales historians were divided within this view between pursuing "microhistory" as a means of accessing locally contextualised worldviews, and a more comprehensive longue-durée approach, looking at historical and economic factors over a long time span. While the latter presented religious change as part of a large-scale social movement, the former focused on unique and idiosyncratic cases of belief and disbelief, yielding studies of heresy, witchcraft, or mysticism (for example Le Roy Laudarie 1978; Ginzburg 1980; Ginzburg 1991). One notable study by a pioneer from the Annales school, Lucien Febvre, explicitly addressed the question of "unbelief" in the sixteenth century on the basis of literary texts of the period (Febvre 1982). Similarly, Jeremy Cohen has taken individual case studies as the basis for a generalised speculation about the "mentality of the medieval Jewish apostate" (Cohen 1987).

Although the Annales focus on mentalities yielded some useful results in the historical study of religion, it also involved speculation about motives and subjectivity on the basis of only fragmentary, narrative sources, sometimes without a thorough accounting of the limitations presented by such sources or the attention to discourse necessary to read them in a meaningful, historicised context. One notable trend in response to these limitations has been to avoid treating religious change as a discreet historical event that can be historicised alongside other events and instead to focus on the histories of representation. This shift is not simply a product of limitations in available sources or 
knowledge, however, but also a methodological shift in the treatment of representations (narratives, images, etc.) as vital aspects of the conversion "event" in themselves. In contrast to Cohen's consideration of the "mentality" of the medieval Jewish apostate, Karl Morrison, on the basis of some of the same sources, argued that, "scholars cannot penetrate to experience through texts, that what we actually can study is a document" (xii). Linking conversion and apostasy as contrary aspects of one conceptual phenomenon, he calls the latter "the keystone of the pathology of conversion" (Morrison 1992: 91), and sees the text as a window not into the "mentality" of the convert but into that of the author who depicted him or the public that imagined him. The narrative approach, shifting from the history of the experience of entering or leaving religion to that of understanding these processes through stories, has been developed in numerous subsequent publications over the last twenty-five years (for example Fredriksen 1986; Deweese 1994; Hindmarsh 2005; Schmitt 2010; Hindmarsh 2014; Szpiech 2013). Similarly, a few studies (Barbour 1994; Viswanathan 1998) have explicitly treated leaving religion (apart from conversion) on the basis of narrative and discourse analysis. Others, taking stock of these methodological changes, have produced similar historical studies according to a more traditional methodology, although often with innovative results (Arnold 2005; Lillevik 2014; Endelman 2015). Selim Deringil, for example, has studied sources in the archives of the Ottoman Empire to argue that "Conversion and/or apostasy were seen as particularly dangerous in the nineteenth-century Ottoman Empire because they were perceived as de-nationalisation" (Deringil 2012: 2-3). An equally innovative approach to the social history of apostasy is Paola Tartakoff's study of the uncommon prosecution of various Jews, converts, and "apostates" by the medieval (papal) Inquisition in fourteenth-century Aragón (Tartakoff 2012: 2-3). Most approaches can be sorted according to what John R. Hall calls "generalizing" versus "particularizing" orientations (Hall 2007: 158-161), each producing different results according to different foci and approaches to language.

\section{4}

Critical Reflections, Evaluations and Predictions

Investigations of religious belief and behaviour before the twentieth century are largely confined to written documents, ritual objects, and visual representations, and these are generally scarcer and more thinly contextualised the further back in time one proceeds. There are usually few or no ethnographic, sociological, or anthropological studies from the period to draw from; evidence 
providing first-hand observations is quite limited, and observations that do survive must be read always as local representations, not scientific or ethnographic records. Moreover, sources of demographic or other numerical data are extremely tenuous. Historians do not have the data or proximity to assess the often complicated motives behind the decision to leave religion. Thus the nuanced distinctions proposed by Zuckerman between "shallow" and "deep" apostasy or "mild" and "transformative" apostasy experiences (Zuckerman 2012: 6-7), which relies on first-hand contact with modern subjects, are virtually impossible for the historian. As Steven Epstein has observed about studying renegades and apostates, "the subject is partly motive, which is always difficult for the historian to fathom" (Epstein 2006: 137), and this difficulty is exacerbated by a lack of extensive or detailed documentation.

Such a lack limits the historian's knowledge and determines the sorts of questions that can and cannot be asked about religious communities and the members who entered and left them. There are, as a result, numerous risks presented by the limitation of information and reliance on written documents that must be carefully avoided when studying leaving religions in the past. Making extrapolated assumptions about motives, identities, beliefs; assigning monolithic and singular identities and perspectives to religious communities; relying on modern categories of the sacred and secular as a measure of a society in which such categories did not exist as such; reading too much into too little information. Many historical studies on conversion and apostasy find themselves limited by one or another of these methodological and theoretical assumptions.

To be sure, historians continue to revise their methodologies in an attempt to avoid past missteps without succumbing to new biases. Gabrielle Spiegel recommends a moderate combination of discourse analysis and scepticism in attending to what she calls the "social logic" of historical sources (Spiegel 1990: 85). Suggestions like these are extremely useful. Yet however carefully they negotiate the pull between text and context in their analysis, historians of all stripes face a stark choice in answering the methodological challenges of the last decades: can the "real" be accessed through texts or not? Is there even a single "real" to be historicised and analysed and if so, how can it be approached? Christine Ames cautions against taking epistemological skepticism too far. "The linguistic turn indeed changed how scholars of religion receive and interpret texts. But they must still, despite source limitations and the difficulty of gauging internal faith from external practice, resist the magnetism of intellectual history, of reducing medieval religion to it" (Ames 2012: 342). The caution makes sense, yet it does not offer a clear course of action out of the impasse: without a solid theoretical basis on which to resist the destabilisation 
of the real brought on by the turn to discourse, that resistance and reduction rely more on faith and imagination than knowledge or understanding. One may study the representations of leaving religion as evidence of cultural history, but, in the absence of extensive testimony, one can only consider motives and experiences by approximation and extrapolation, and along this path lie formidable risks of interpretive bias.

In an attempt to avoid imposing overly simple characterisations of belief in historiography, Marc Baer proposes four categories for conversion in history: "acculturation" (incorporation into a larger cultural system), "adhesion/ hybridity" (adopting new beliefs and practices alongside the old), "syncretism" (fusion of old and new), and "transformation" (total replacement of the old with the new) (Baer 2014: 25-26;). Adapting Baer's view, we can propose characterising leaving religion according to comparable, parallel categories: "distancing" (cultural and geographic separation to mark departure from belief systems and a waning of ritual practice without a certain change of beliefs); "de-ritualisation" (an abandonment of former practices and beliefs alongside a certain persistence of a generalised spiritual sensibility); "deconversion" (a marked temporal and historical rupture with old ways and beliefs without a certain stance, whether positive or negative, on any new spirituality); and "secularisation" (a total rejection of any religious sensibility in favor of a nonreligious worldview and practice). These categories represent a spectrum of positions towards former and current ideas about religion and identity and might serve, as least in a heuristic sense, to account for the varieties of experience implied by the broad notion of "leaving religion."

To apply these terms to the example with which we began, that of Abner of Burgos/Alfonso of Valladolid, we might ask how one may write a historical account of his departure from Judaism. Should historians attempt to date his "distancing" in social terms according to his actions (baptism, adherence to a new social group, etc.) or in affective terms according to his own statements about his inner doubts and isolation? Because he wrote in Hebrew and by all accounts approached Christianity through mostly Jewish paradigms, we might say that he never "deconverted" from Judaism, as Shamir implies, but only that he "de-ritualised," as Yitzhak Baer's reading suggests, making him more of a Jewish apostate than a Christian convert. He did not, in any case, become secularised to a purely philosophical worldview outside of religion, thus although he left one religion for another, he did not "leave religion" altogether. Was he 
more a "heretic," or more a "Jew at heart"? While these questions remain difficult to answer, we can be more certain that Abner/Alfonso is notable because his account of leaving Judaism is one of the best autobiographical accounts of religious change from the Iberian Peninsula, and thus his representation of his experience fits coherently into a larger chronology of conversion and apostasy narratives in the Middle Ages.

The case of Abner of Burgos/Alfonso of Valladolid underscores the difficulty of establishing the study of "leaving religion" as an independent historical area. Whether the historian follows the categorical distinctions offered above, or other ones, the challenge she faces is how to represent historical change without relying on pietistic or presentist hierarchies and value structures that see leaving religion either in negative terms (as a "loss of faith") or in positive ones (as a "rational" break with superstition), and at the same time without filling in data with information about "typical" experiences where such material is obscure or lacking in the source record. As historiographical writing more generally takes ever greater stock of individual actors and perspectives in an effort to characterise experience, identity, and agency in historical terms, so the historiography of religion might best strive to offer not a history of religious belief or unbelief per se but a critical ethnography of the production and use of religious symbols and narratives by specific communities and individuals. As Foucault argues, it should eschew "a reading that would bring back, in all its purity, the distant, precarious, almost effaced light of the origin" and instead commit itself only to "the systematic description of the discourse-object" (1972: 140). In other words, the study of leaving religion in a historical context might do best to attend principally to how leaving religion is depicted, resisting the tendency to generalise too much from representations to historical events.

\section{References}

Ames, C.C. 2012. "Medieval Religious, Religions, Religion." History Compass. 10:4, $334-35^{2}$.

Arnold, J.H. 2005. Belief and Unbelief in Medieval Europe. London: Hodder Arnold.

Aubin, C. 1963. Le problème de la conversion: Étude sur un terme commun à l'hellénisme et au christianisme des trois premiers siècles. Paris: Beauchesne et Fils.

Baer, M.D. 2014. "History and Religious Conversion." In L.R. Rambo and C.E. Farhadian, eds., The Oxford Handbook of Religious Conversion. New York: Oxford University Press, 25-47.

Baer, Y. 1961. A History of the Jews in Christian Spain. Trans. L. Schoffman. 2 vols. Philadelphia: Jewish Publication Society of America. 
Barbour, J.D. 1994. Versions of Deconversion: Autobiography and the Loss of Faith. Charlottesville: University Press of Virginia.

Bulliet, R. 1979. Conversion to Islam in the Medieval Period: An Essay in Quantitative History. Cambridge, Mass.: Harvard University Press.

Clark, E.A. 2004. History, Theory, Text: Historians and the Linguistic Turn. Cambridge, Mass.: Harvard University Press.

Cohen, J. 1999. "Between Martyrdom and Apostasy: Doubt and Self-Definition in the Twelfth-Century Askenaz." Journal of Medieval and Early Modern Studies. 29, 431-471.

Cohen, J. 1987. "The Mentality of the Medieval Jewish Apostate: Peter Alfonsi, Hermann of Cologne, and Pablo Christiani." In T. Endelman, ed., Jewish Apostasy in the Modern World. New York: Holmes and Meier, 20-47.

Deringil, S. 2012. Conversion and Apostasy in the Late Ottoman Empire. Cambridge: Cambridge University Press.

Deweese, D. 1994. Islamization and Native Religion in the Golden Horde: Baba Tükles and Conversion to Islam in Historical and Epic Tradition. University Park: Pennsylvania State University Press.

Edwards, J. 1988. "Religious Faith and Doubt in Late Medieval Spain: Soria, circa 1450-1500." Past and Present. 120, 3-25.

Endelman, T. 2015. Leaving the Jewish Fold: Conversion and Radical Assimilation in Modern Jewish History. Princeton: Princeton University Press.

Epstein, S.A. 2006. Purity Lost: Transgressing Boundaries in the Eastern Mediterranean 1000-1400. Baltimore: The Johns Hopkins University Press.

Febvre, L. 1982 [1937]. The Problem of Unbelief in the Sixteenth Century: The Religion of Rabelais. Cambridge, Mass.: Harvard University Press.

Fletcher, R. 1997. The Barbarian Conversion. From Paganism to Christianity. New York: Henry Holt.

Foucault, M. 1972. The Archaeology of Knowledge and the Discourse on Language. Trans. A.M. Sheridan Smith. New York: Pantheon.

Fredriksen, P. 1986. "Paul and Augustine: Conversion Narratives, Orthodox Traditions, and the Retrospective Self." Journal of Theological Studies. New Ser. 37, 3-34.

Ginzburg, C. 1980. The Cheese and the Worms: The Cosmology of a Sixteenth-Century Miller. Baltimore: The Johns Hopkins University Press.

Ginzburg, C. 1991. Ecstasies: Deciphering the Witches Sabbath. Chicago: University of Chicago Press.

Grundmann, H. 1995 [1953]. Religious Movements in the Middle Ages. Trans. S. Rowan. South Bend: Notre Dame University Press.

Hall, J.R. 2007. "History, Methodologies and the Study of Religion." In James Beckford and N.J. Demerath III, eds., The SAGE Handbook of the Sociology of Religion. London: Sage, 151-172.

Hindmarsh, B. 2005. The Evangelical Conversion Narrative: Spiritual Autobiography in Early Modern England. Oxford: Oxford University Press. 
Hindmarsh, B. 2014. "Religious Conversion as Narrative and Autobiography." In L.R. Rambo and C.E. Farhadian, eds., The Oxford Handbook of Religious Conversion. New York: Oxford University Press, 25-47.

James, W. 1987. Writings 1902-1910. Washington, D.C.: Library of America.

Jay, M. 1982. "Should Intellectual History Take a Linguistic Turn? Reflections on the Habermas-Gadamer Debate." In D. LaCapra and S.L. Kaplan, eds., Modern European Intellectual History: Reappraisals and New Perspectives. Ithaca: Cornell University Press, 86-110.

Jones, A.H.M. 1962. Constantine and the Conversion of Europe. Toronto: Toronto University Press.

Jospe, R. 1988. Filosofiah Yehudit ma-hi? [What is Jewish Philosophy?] Jerusalem: Open University of Israel [Hebrew].

Kanarfogel, E. 2012. "Changing Attitudes toward Apostates in Tosafist Literature, Late Twelfth-Early Thirteenth Centuries.” In E. Carlebach and J. Schacter (eds.), New Perspectives on Jewish-Christian Relations. Leiden: Brill, 297-327.

Lillevik, R. 2014. Apostates, Hybrids, or True Jews?: Jewish Christians and Jewish Identity in Eastern Europe 1860-1914. Eugene, Oregon: Pickwick.

Leff, G. 1967. Heresy in the Later Middle Ages: The Relation of Heterodoxy to Dissent, c. 1250-c. 145o. Manchester: Manchester University Press.

Leone, M. 2004. Religious Conversion and Identity: The Semiotic Analysis of Texts. London: Routledge.

Le Roy Ladurie, E. 1978. Montaillou. The Promised Land of Error. Trans. Barbara Bray. New York: George Braziller.

Malkiel, D. 2007. "Jews and Apostates in Medieval Europe-Boundaries Real and Imagined." Past and Present. 194, 3-34.

Moore, R.I. 1975. The Birth of Popular Heresy. Toronto: University of Toronto Press.

Morrison, K.F. 1992. Understanding Conversion. Charlottesville, VA: Virginia University Press.

Nock, A.D. 1933. Conversion: The Old and the New in Religion from Alexander the Great to Augustine of Hippo. Oxford: Oxford University Press.

Popkin, R.H. 1979. The History of Skepticism from Erasmus to Spinoza. Berkeley: University of California Press.

Proudfoot, W. 1985. Religious Experience. Berkeley: University of California Press.

Rambo, L. 1993 Understanding Religious Conversion. New Haven: Yale University Press.

Russell, J. 1965. Dissent and Reform in the Early Middle Ages. Berkeley: University of California Press.

Schmitt, J.-C. 2010. The Conversion of Herman the Jew. Autobiography, History, and Fiction in the Twelfth Century. Trans. A.J. Novikoff. Philadelphia: University of Pennsylvania Press.

Shamir, Y. 1975. Rabbi Moses Ha-Kohen of Tordesillas and His Book "Ezer Ha-Emunah." Leiden: Brill. 
Skinner, Q. 1969. "Meaning and Understanding in the History of Ideas." History and Theory. 8:10, 3-53.

Spiegel, G.M. 1990. "History, Historicism, and the Social Logic of the Text in the Middle Ages." Speculum. 65, 59-86.

Strenski, I. 1993. Religion in Relation: Method, Application, and Moral Location. Columbia: University of South Carolina Press.

Stromberg, P.G. 1993. Language and Self-Transformation: A Study of the Christian Conversion Narrative. Cambridge: Cambridge University Press.

Szpiech, R. 2013. Conversion and Narrative: Reading and Religious Authority in Medieval Polemic. Philadelphia: University of Pennsylvania Press.

Szpiech, R. 2017. "Conversion as a Historiographical Problem." In Y. Fox and Y. Yisraeli, eds., Contesting Inter-Religious Conversion in the Medieval World. Abingdon and New York: Routledge.

Tartakoff, P. 2012. Between Christian and Jew: Conversion and Inquisition in the Crown of Aragon, 1250-1391. Philadelphia: University of Pennsylvania Press.

Toews, J.E. 1987. "Intellectual History after the Linguistic Turn: The Autonomy of Meaning and the Irreducibility of Experience." American Historical Review 92:4, 879-907.

Tuck, R. 1988. "Skepticism and Toleration in the Seventeenth Century." In S. Mendus, ed., Justifying Toleration: Conceptual and Historical Perspectives. Cambridge: Cambridge University Press, 21-37.

Vásquez García, F. 2004. "The Linguistic Turn and Postmodernity among Spanish Historians." In C. Barros and J. McCrank, eds., History Under Debate. International Reflection on the Discipline. New York: Haworth Press, 59-81.

Viswanathan, G. 1998. Outside the Fold: Conversion, Modernity, and Belief. Princeton: Princeton University Press.

Zuckerman, P. 2012. Faith No More: Why People Reject Religion. New York: Oxford University Press. 